\title{
Study on the efficiency of sequential batch reactor (SBR)-based sewage treatment plant
}

\author{
Uzma Showkat ${ }^{1}$. Ishtiyaq Ahmed Najar ${ }^{2}$
}

Received: 7 December 2016 / Accepted: 22 November 2018 / Published online: 1 December 2018

(c) The Author(s) 2018

\begin{abstract}
The present study was carried out to evaluate the performance of 16.1 MLD sewage treatment plant (STP) located at Brari Nambal (J\&K), India. The STP is based on sequential batch reactor (SBR) technology. Wastewater (influent and effluent) samples were analyzed for 14 different physicochemical parameters. Significant variation $(P<0.05)$ was recorded within and among the wastewaters in $\mathrm{pH}\left(F_{11,1}=7.49,26\right)$, electrical conductivity $\left(F_{11,1}=12.13,49.94\right)$, calcium $\left(F_{11,1}=8.58,91.66\right)$, magnesium $\left(F_{11,1}=4.68,132.37\right)$, chloride $\left(F_{11,1}=10.18,74.85\right)$, sodium $\left(F_{11,1}=11.31,192.64\right)$, potassium $\left(F_{11,1}=5.98\right.$, $52.22)$ and chemical oxygen demand $\left(F_{11,1}=4.16,267.65\right)$, whereas among the wastewaters in total suspended solids $\left(F_{1}=165.21\right)$, total dissolved solids $\left(F_{1}=150.40\right)$, biological oxygen demand $\left(F_{1}=307.89\right)$, ortho-phosphate $\left(F_{1}=624.54\right)$, total phosphorous $\left(F_{1}=336.85\right)$ and nitrate nitrogen $\left(F_{1}=68.10\right)$. Significant negative correlation exists between TSS and $\mathrm{EC}(r=-0.796 ; P<0.01)$ and $\mathrm{Cl}$ and $\mathrm{Ca}(r=-0.646 ; P<0.05)$, whereas significant positive correlation between $\mathrm{BOD}_{5}$ and $\mathrm{Ca}(r=0.579 ; P<0.05)$, COD and TSS $(r=0.728 ; P<0.01)$ and ortho-phosphate and $\mathrm{pH}(r=0.791 ; P<0.01)$. Maximum decrease was recorded in TP (68.37\%) followed by $\mathrm{NO}_{3}-\mathrm{N}(64.88 \%)$, COD (63.79\%), BOD (59.38\%), OP (55.94\%), TDS (44.82\%) and least in TSS (38\%) among parameters which are of prime concern. Six principal components (PCs) have been identified by factor analysis which explained $90.30 \%$ of total variance, representing alkaline factor, salts/ions factor, household/water usage factor, dissolved salts factor, soaps/detergents factor and catchment factor. Thus, least reduction in concentration of ortho-phosphate, TDS and TSS is concern when the effluent is disposed off in a water body which is already under the stress of nutrient enrichment/pollution.
\end{abstract}

Keywords Effluent · Influent · Sequential batch reactor · Sewage treatment plant

\section{Introduction}

Wastewater discharged from residences, institutions and commercial establishments is termed as sewage. The composition of wastewater is a reflection of the life styles and technologies practiced in the producing society (Edwin et al. 2014; Gray 1989). Normally, domestic/municipal wastewater is composed of $99.9 \%$ water and remaining $0.1 \%$ suspended, colloidal and dissolved solids, mainly organic in nature, as it consists of larger proportion of carbon compounds such as human excreta, paper, vegetable matter and microorganisms

Ishtiyaq Ahmed Najar

ishtiyaq.env@gmail.com

1 P.G Department of Environmental Sciences, S.P College, Srinagar, Kashmir (J\&K) 190001, India

2 Department of Environmental Sciences, G.D College, Ganderbal, Kashmir (J\&K) 191201, India
(Gautam et al. 2013). Three quarters of organic carbon in sewage are present as carbohydrates, fats, proteins, amino acids and volatile acids. The inorganic constituents include large concentrations of sodium, calcium, potassium, magnesium, chlorine, sulfur, phosphate, bicarbonate, ammonium salts and heavy metals (Chen et al. 2018: Horan 1990; Lim et al. 2011). In order to minimize the environmental and health hazards (Singh et al. 2015; Jafarinejad 2017; Khudair and Jasim 2017; Kominko et al. 2018), these constituents need to be brought down to permissible limits. Therefore, removal of the nutrients, organic contaminants and pathogens from wastewater is of paramount importance in order to prevent eutrophication, oxygen depletion and toxicity (Najar and Khan 2011, 2012, 2013; Najar 2017; Ajala et al. 2018). Further, there are some strict criteria for discharging effluents containing nitrogen and phosphorus, especially in environmentally sensitive areas. 
Sequencing batch reactor (SBR) as compared to traditional or conventional treatments is an easily obtainable, on timescale, highly operational, flexible technology for newer and varied pollutants (Popple et al. 2016; Dutta and Sarkar 2015); Kulkarni 2013). The SBR systems have many advantages such as lower operational cost, less bulking and higher flexibility to combine nitrification and denitrification phases into one reactor (Lim et al. 2011) with good removal efficiency for nitrogen, phosphorus and chemical oxygen demand (Khan et al. 2017; Ding et al. 2011).

Evaluation on performance of treatment plants is required to assess the existing effluent quality and/or to meet treatment requirements (Sekhar et al. 2014). The efficiency of sewage treatment plants can be evaluated by measuring the concentration of pollutant in the influent and effluent (Metcalf and Eddy 2003). Keeping in view of the above facts, the present investigation was carried to study the efficiency of sewage treatment plant by analyzing the different physiochemical characteristics of influent and effluent.

\section{Materials and methods}

The study was carried out at Brari Nambal STP located at Srinagar, Jammu and Kashmir, India, located within the geographical coordinates of $34^{\circ} 0869 \mathrm{~N}, 74^{\circ} 8139 \mathrm{E}$, with a total capacity of 16.10 MLD. The STP is based on sequential batch reactor (SBR) technology. Disposal site for treated sewage (effluent) is Brari Nambal (small fresh water body and was previously part of Dal Lake). The catchment area of the STP includes Saida Kadal, Hathi-Khan, Gorepora, Naidyar, Jogilanker, Miskeenbagh, Daulatabad, Naqashpora, Baba dawood Khaki Bridge, Brari Nambal, Khonakhun area, Nehru Park, Dalgate and Bishembar Nagar.

\section{Collection and analysis of wastewater samples}

Wastewater samples were collected on a monthly basis from inlet and outlet of the STP during morning hours for a period of 1 year in white plastic containers that were prior cleaned with metal-free soap, rinsed repeatedly with distilled water, then soaked in $10 \%$ nitric acid for $24 \mathrm{~h}$ and finally rinsed with ultrapure water. All water samples were stored in insulated cooler containing ice and taken on the same day to laboratory and stored at $4{ }^{\circ} \mathrm{C}$ until processing and analysis (APHA 2005). $\mathrm{pH}$ and electrical conductivity (EC) were determined by $\mathrm{pH}$ meter (Bates 1978) and conductivity meter (Jasper 1988), respectively. Calcium (Ca) and magnesium $(\mathrm{Mg})$ concentrations were determined by the versenate method (Kat and Navone 1964). Sodium $(\mathrm{Na})$ and potassium $(\mathrm{K})$ were analyzed using flame photometer (Thompson and Reynolds 1978). Biochemical oxygen demand $\left(\mathrm{BOD}_{5}\right)$ was determined using incubation method
(Mancy and Jaffe 1966). Chemical oxygen demand (COD) was determined using reflux method (Pitwell 1983). Phosphate phosphorous $\left(\mathrm{PO}_{4}-\mathrm{P}\right)$ was determined by molybdate method (Edwards et al. 1965), and nitrate nitrogen $\left(\mathrm{NO}_{3}-\mathrm{N}\right)$ was determined by phenyldisulfonic acid method (Brown and Bellinger 1978), respectively, using spectrophotometer.

\section{Results and discussion}

Sequence batch reactor (SBR) process can remove carbonaceous constituents $\left(\mathrm{BOD}_{5}, \mathrm{COD}\right.$ and TSS) efficiently up to the level of $90 \%$ (Dohare and Kawale 2014; Obaja et al. 2005). Mahvi et al. (2004) reported COD removal efficiency above $94.90 \%$ in SBR-based treatment system as the treatment system has ability to remove organic carbon and a better resistance against variable loadings, which suggests that reactor is able to guarantee process stability. Fernandes et al. (2013) also reported removal efficiency of TSS and volatile suspended solids (VSS) by $70 \%$ and $80 \%$, respectively.

The physiochemical characteristics of influent and effluent are given in Fig. 1, and the correlation matrix of different parameters is given in Table 1. $\mathrm{pH}$ is one of the important parameters in wastewater treatment (Salunke et al. 2014). $\mathrm{pH}$ of the wastewater was alkaline and exhibited a mean value of $8.24 \pm 0.07$ and $8.35 \pm 0.05$ for influent and effluent, with significant variation within $\left(F_{11}=7.49, P<0.05\right)$ and among $\left(F_{1}=26, P<0.05\right)$ the wastewaters (influent and effluent). Gautam et al. (2013) also reported the alkaline nature of the municipal wastewater. Increase in alkaline nature of the wastewater after treatment has been reported by Sharma et al. (2013). Akan et al. (2008) reported higher $\mathrm{pH}$ values for effluents as compared to influent. The $\mathrm{pH}$ of effluent determines its usefulness for a variety of purposes as very high or low $\mathrm{pH}$ is toxic to aquatic life and also alters the solubility of essential elements and chemical pollutants (Morrison et al. 2001).

Conductivity is a general indicator of wastewater quality, especially a function of the amount of dissolved salt, and is used to monitor processes in the wastewater treatment that causes changes in total salt concentration which in turn changes the conductivity (Aguado et al. 2006). EC showed significant variation within $\left(F_{11}=12.13, P<0.05\right)$ and among $\left(F_{1}=49.94, P<0.05\right)$ wastewaters, with a value of $626.5 \pm 21.43 \mu \mathrm{S} / \mathrm{cm}$ for influent, and for effluent values were $573 \pm 30.18 \mu \mathrm{S} / \mathrm{cm}$ with mean removal efficiency of $8.53 \%$. The high EC value is attributed to the high salinity and high mineral content. It also corresponds to the highest concentrations of dominant ions which are the result of ion exchange and solubilization in the water Gautam et al. (2013). The results are consistent with the findings of Rizvi et al. (2015) and Jan and Rafiq (2012) that there is 
Fig. 1 Box-and-whisker plots of physiochemical characteristics of influent and effluent (open circles and asterisk denote outliers with 1.59 interquartile range (IQR) and $3 \mathrm{IQR}$, respectively)
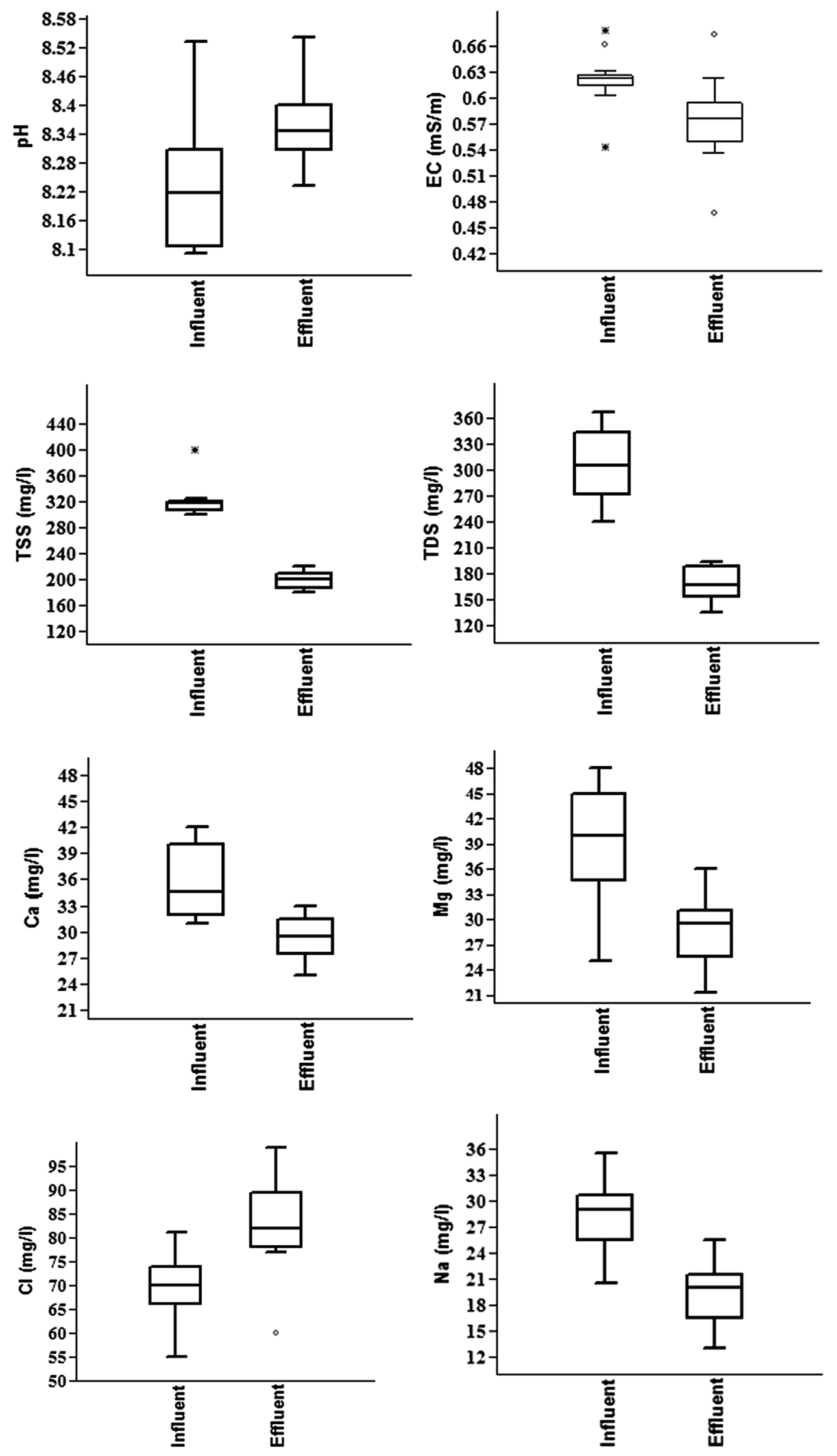
Fig. 1 (continued)
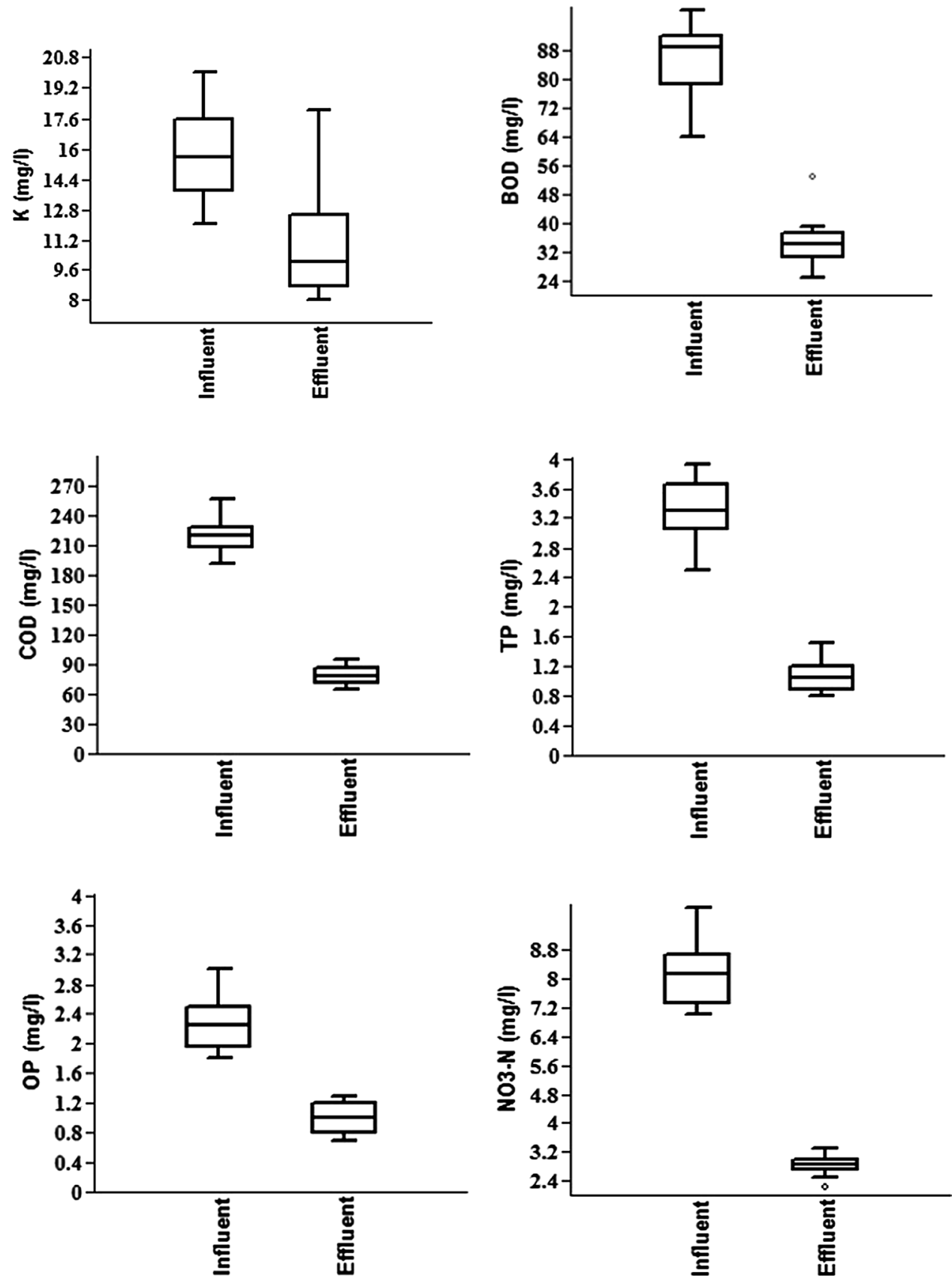

reduction in EC after treatment and is attributed to removal of salts-nitrates, ammonium, cations and associated chemicals (Lamichhane et al. 2011).

TSS is a measure of the floating particulate content of the wastewater and is an indicator of the clarity of the wastewater (Johal et al. 2014). Total suspended solids for influent were $321.11 \pm 17.44 \mathrm{mg} / \mathrm{l}$. The value was reduced for effluent to $199.06 \pm 14.10 \mathrm{mg} / \mathrm{l}$ with mean removal efficiency of $38 \%$. The variation in TSS was significant among $\left(F_{1}=165.21, P<0.05\right)$ wastewaters and non-significant within them $\left(F_{11}=0.54, P<0.05\right)$. The decrease in total solids could be attributed to sedimentation process undergoing during the treatment. Decrease in TSS after treatment has also been reported by Khan et al. (2014). Mahvi et al. (2008) and Patel et al. (2013) conducted studies on reduction in TSS from wastewaters using SBR-based treatment and indicated removal efficiencies of $99 \%$ and $95.41 \%$, respectively. TSS showed highly significant negative correlation with EC ( $r=-0.796 ; P<0.01)$ as TSS had no contribution to salt concentration (EC) as compared to TDS. Negative correlation between TSS and EC has been reported by Bhandari and Nayal (2008), whereas positive correlation between TDS and EC by (Gautam et al. 2013). 
Table 1 Correlation matrix of influent

\begin{tabular}{|c|c|c|c|c|c|c|c|c|c|c|c|c|c|c|}
\hline & $\mathrm{pH}$ & $\mathrm{EC}$ & TSS & TDS & $\mathrm{Ca}$ & $\mathrm{Mg}$ & $\mathrm{Cl}$ & $\mathrm{Na}$ & K & $\mathrm{BOD}_{5}$ & COD & $\mathrm{P}$ & TP & $\mathrm{NO}_{3}-\mathrm{N}$ \\
\hline $\mathrm{pH}$ & 1 & & & & & & & & & & & & & \\
\hline $\mathrm{EC}$ & -0.049 & 1 & & & & & & & & & & & & \\
\hline TSS & -0.008 & $-0.796 * *$ & 1 & & & & & & & & & & & \\
\hline TDS & -0.158 & 0.047 & -0.125 & 1 & & & & & & & & & & \\
\hline $\mathrm{Ca}$ & -0.161 & -0.257 & 0.295 & -0.135 & 1 & & & & & & & & & \\
\hline $\mathrm{Mg}$ & -0.381 & 0.2 & 0.237 & -0.02 & 0.312 & 1 & & & & & & & & \\
\hline $\mathrm{Cl}$ & -0.079 & 0.066 & -0.408 & 0.35 & $-0.646^{*}$ & -0.299 & 1 & & & & & & & \\
\hline $\mathrm{Na}$ & 0.374 & 0.572 & -0.31 & -0.281 & -0.283 & 0.201 & -0.056 & 1 & & & & & & \\
\hline K & 0.217 & 0.43 & -0.164 & 0.574 & -0.218 & 0.211 & 0.162 & 0.326 & 1 & & & & & \\
\hline $\mathrm{BOD}_{5}$ & -0.495 & -0.162 & 0.06 & -0.299 & $0.579 *$ & 0.208 & -0.159 & -0.216 & -0.493 & 1 & & & & \\
\hline COD & -0.5 & -0.417 & $0.728 * *$ & -0.007 & 0.34 & 0.54 & -0.427 & -0.341 & -0.154 & 0.386 & 1 & & & \\
\hline $\mathrm{OP}$ & $0.791 * *$ & 0.269 & -0.355 & 0.056 & 0.129 & -0.244 & -0.157 & 0.283 & 0.301 & -0.213 & -0.509 & 1 & & \\
\hline TP & -0.168 & 0.134 & -0.289 & 0.12 & -0.155 & -0.185 & 0.392 & 0.313 & -0.061 & 0.222 & -0.332 & -0.171 & 1 & \\
\hline $\mathrm{NO}_{3}-\mathrm{N}$ & -0.12 & 0.426 & -0.387 & -0.184 & -0.426 & -0.024 & 0.008 & 0.409 & -0.203 & 0.013 & 0.008 & -0.052 & -0.031 & 1 \\
\hline
\end{tabular}

*Significance at 0.05 level and **significance at 0.01 level

The TDS value of the wastewater is mainly due to the ions/salts added during the use of water (Salunke et al. 2014). Significant variation $\left(F_{1}=150.40, P<0.05\right)$ was recorded among wastewaters (influent and effluent), whereas nonsignificant $\left(F_{11}=1.96, P<0.05\right)$ within them. Value of total dissolved solids for influent was $306 \pm 39.40 \mathrm{mg} / \mathrm{l}$ while as for effluent value was reduced to $168.83 \pm 20.28 \mathrm{mg} / \mathrm{l}$ with mean removal efficiency of $44.82 \%$. Ukpong (2013) also reported decrease in TSS after treatment. The decrease in TDS may be because of oxidative degradation of dissolved solid (Singh and Varshney 2013). Mahvi et al. (2008) conducted study on removal of TDS from wastewaters using SBR method and reported removal efficiencies of $61.25 \%$.

The main sources of $\mathrm{Ca}$ and $\mathrm{Mg}$ in wastewater are calcite, dolomite, magnesite, anhydrite, gypsum feldspar, pyroxene and amphiboles present in catchment. Calcium hardness for influent was $35.67 \pm 2.33 \mathrm{mg} / \mathrm{l}$, and for effluent value was reduced to $29.33 \pm 2.04 \mathrm{mg} / \mathrm{l}$ with mean removal efficiency of $17.77 \%$. Magnesium exhibited a value of $38.82 \pm 8.14 \mathrm{mg} / \mathrm{l}$ for influent and effluent with a concentration of $28.53 \pm 3.52 \mathrm{mg} / \mathrm{l}$ with mean removal efficiency of $26.50 \%$. The reduction in $\mathrm{Ca}$ has been reported by the findings of Kushwah et al. (2011) and Jan and Rafiq (2012). Calcium and magnesium exhibited significant variation within $\left(\mathrm{Ca} F_{11}=8.58 ; \mathrm{Mg} F_{11}=4.68, P<0.05\right)$ and among $\left(\mathrm{Ca} F_{1}=91.66 ; \mathrm{Mg} F_{1}=132.37, P<0.05\right)$ wastewaters. Decrease in concentration could be attributed to the grit separation, sedimentation process and active uptake of calcium and magnesium by microorganisms during treatment (Nathanson 2003).
Chloride for influent was $69.15 \pm 5.07 \mathrm{mg} / \mathrm{l}$ while as for effluent the value increased to $82.83 \pm 6.59 \mathrm{mg} / \mathrm{l}$ with an increase of $19.78 \%$. Significant variation in chloride was recorded within $\left(F_{11}=10.18, P<0.05\right)$ and among $\left(F_{1}=74.85, P<0.05\right)$ the influent and effluent. Higher concentration of chloride in sewage may result from the higher usage of washing agents like detergents, soaps and water filtering units, sodium chloride and also by discharging fecal matter (Von Sperling 1996). Chloride ion concentration is an important factor to be considered if the effluent is used for irrigation. $\mathrm{Cl}$ exhibited significant negative correlation with $\mathrm{Ca}(r=-0.646 ; P<0.05)$ which indicates there are different sources as $\mathrm{Ca}$ is mainly attributed by catchment.

The natural source of $\mathrm{Na}$ in wastewater is weathering of plagioclase, pyroxene and hornblende from catchment (Najar and Khan 2012), in addition to household sources. Significant variation in sodium was observed within $\left(F_{11}=11.31\right.$, $P<0.05)$ and among $\left(F_{1}=192.64, P<0.05\right)$ the wastewaters with a value of $28.08 \pm 1.97 \mathrm{mg} / \mathrm{l}$ for influent while as it was $19.41 \pm 1.82 \mathrm{mg} / \mathrm{l}$ for effluent with removal efficiency of $30.87 \%$. Higher concentration of sodium in wastewater may be as a result of excess usage of synthetic detergents by households and consumption of sodium chloride in addition to catchment source. Decrease in $\mathrm{Na}$ concentration in effluent could be due to exponential growth phase during biological treatment which resulted in the active uptake of potassium ion from sewage.

The natural sources of $\mathrm{K}$ are weathering of orthoclase, microcline, biotite and K-feldspar Gautam et al. (2013). Value of potassium for influent was $15.83 \pm 1.23 \mathrm{mg} / \mathrm{l}$ and 
$11.17 \pm 1.18 \mathrm{mg} / \mathrm{l}$ for effluent with a mean removal efficiency of $29.43 \%$. Significant variation in $\mathrm{K}$ was recorded within $\left(F_{11}=5.98, P<0.05\right)$ and among $\left(F_{1}=52.22, P<0.05\right)$ the influent and effluent. Wastewater exhibits higher concentration of potassium which may be attributed to the increase in the discharge of human excretory material as the urine fraction that contains $80 \%$ of the potassium (Claesson and Steineck 1996)

$\mathrm{BOD}_{5}$ varied significantly $\left(F_{1}=307.89, P<0.05\right)$ between and insignificantly $\left(F_{11}=0.91, P<0.05\right)$ among wastewaters with a mean value of $85.33 \pm 4.75 \mathrm{mg} / \mathrm{l}$ and $34.66 \pm 2.24 \mathrm{mg} / \mathrm{l}$ for influent and effluent, respectively. BOD removal is indicative of the efficiency of biological treatment processes and is the most widely used parameter to measure wastewater quality. $\mathrm{BOD}_{5}$ value of effluent showed a significant decrease with removal efficiencies of $59.38 \%$, and the reduction may be attributed to batch reactors which allow more oxidation of organic matter. Wakode and Sayyad (2016) also reported BOD reduction from $134.63 \mathrm{mg} / \mathrm{l}$ to $5.36 \mathrm{mg} / \mathrm{l}$, with removal efficiency of $96 \%$ by using SBR process. Reduction in BOD has also been confirmed by the studies of Kushwah et al. (2011) and Ukpong (2013). Significant positive correlation of BOD with $\mathrm{Ca}(r=0.579 ; P<0.05)$ indicates some of the organic matter is attributed by catchment runoff in addition to water usage in households.

COD is the amount of oxygen consumed by the chemical breakdown of organic and inorganic matter and mainly serves to measure the ability of organic substances to consume oxygen in water (Akan et al. 2008). Significant variation in COD was recorded within $\left(F_{11}=4.16\right.$, $P<0.05)$ and between $\left(F_{1}=267.65, P<0.05\right)$ the influent and effluent with a mean value of $218.67 \pm 8.92 \mathrm{mg} / \mathrm{l}$ and $79.16 \pm 7.05 \mathrm{mg} / \mathrm{l}$, respectively. The overall removal efficiency was $63.79 \%$. Higher levels of COD in wastewater lead to drastic oxygen depletion once discharged into water body and adversely effect the biota. The decrease may be linked to the aeration and digestion processes, which has also been confirmed by Tian et al. (2011), Ghehi et al. (2014), Johal et al. (2014) and Ding et al. (2011) by $90 \% 94 \%, 98 \%$ and $99 \%$, respectively. Highly significant positive correlation $(r=0.728 ; P<0.01)$ of COD with TSS shows that increase in TSS increases the COD and TSS is composed of both organic and inorganic substances. Kokkinos et al. (2015) also reported positive correlation between COD and TSS.

The total phosphorous in municipal wastewater consists of $70-90 \%$ soluble orthophosphates and $30-10 \%$ organically bound phosphorous which is in soluble or particulate form, a small fraction of unbiodegradable phosphorous (Ekama and Marais 1984). Phosphate in sewage effluents arises from human wastes and domestic phosphate-based detergents and soaps (Ogunfowokan et al. 2005). Phosphorous is one of the important elements for the growth of algae, and its concentration in wastewater discharges has to be controlled/reduced in order to avoid noxious algal blooms. Total phosphorous showed insignificant $\left(F_{11}=0.69, P<0.05\right)$ variation within, but significant $\left(F_{1}=336.85 P<0.05\right)$ among wastewaters. Mean values of total phosphorous showed reduction from $3.32 \pm 0.66 \mathrm{mg} / \mathrm{l}$ to $1.05 \pm 0.15 \mathrm{mg} / \mathrm{l}$ with mean removal efficiency of $68.37 \%$. The decrease in total phosphorous may be attributed to various phenomena such as adsorption, precipitation and/or assimilation by microorganisms during the process of treatment (Rajeb et al. 2011). The result is consistent with the findings of Wakode and Sayyad (2016) and reported removal efficiency of $71.79 \%$.

Ortho-phosphate or inorganic phosphate is often referred to as reactive phosphorous. It is the form most readily available to plants and thus may be the most useful indicator of excessive plant and algal growth (Wenzel and Ekama 1997). Variation was insignificant $\left(F_{11}=2.31\right.$, $P<0.05)$ within wastewaters, but significant $\left(F_{1}=624.54\right.$, $P<0.05)$ among them. Ortho-phosphorus of influent was $2.27 \pm 0.96 \mathrm{mg} / \mathrm{l}$ while as for effluent it was reduced to $1 \pm 0.15 \mathrm{mg} / 1$ showing a mean removal efficiency of $55.94 \%$. Highly significant positive correlation $(r=0.791$; $P<0.01)$ exists between ortho-phosphate and $\mathrm{pH}$. The results are in agreement with that of Mehdi and Rafiq (2012).

Nitrate nitrogen represents the end product of oxidation of nitrogenous matter, and its concentration depends on the nitrification and denitrification activities of microorganism (Mehdi and Rafiq 2013). Nitrates are inorganic sources of nitrogen that support the growth and development of fresh water weeds. However, increased levels of nitrate nitrogen result in nutrient enrichment (eutrophication) causing excessive plant growth, algal blooms, loss of diversity and overall ecosystem degradation (Emmanuel et al. 2010). Nitrate nitrogen showed decrease in mean values from $8.10 \pm 1.48 \mu \mathrm{g} / \mathrm{l}$ to $2.82 \pm 0.65 \mu \mathrm{g} / \mathrm{l}$ with mean removal efficiency of $65.18 \%$. Nitrate nitrogen was insignificant $\left(F_{11}=1.85, P<0.05\right)$ within, whereas significant $\left(F_{1}=68.10, P<0.05\right)$ among influent and effluent. The results were consistent with those of Singh and Varshney (2013) and Sharma et al. (2013) as they reported nitrate nitrogen removal efficiency of more than $80 \%$. 
Table 2 Factor loading values and explained variance of influent

\begin{tabular}{|c|c|c|c|c|c|c|}
\hline Parameter & $\mathrm{PC} 1$ & $\mathrm{PC} 2$ & PC3 & PC4 & PC5 & PC6 \\
\hline $\mathrm{pH}$ & 0.936 & -0.151 & -0.186 & -0.048 & -0.098 & 0.141 \\
\hline EC & 0.058 & 0.856 & -0.056 & 0.183 & 0.028 & 0.403 \\
\hline TSS & -0.200 & -0.919 & 0.083 & -0.085 & -0.278 & 0.105 \\
\hline TDS & -0.121 & 0.066 & -0.111 & 0.856 & 0.058 & -0.253 \\
\hline $\mathrm{Ca}$ & -0.009 & -0.191 & 0.946 & -0.044 & -0.151 & -0.027 \\
\hline $\mathrm{Mg}$ & -0.486 & -0.028 & 0.323 & 0.208 & -0.242 & 0.634 \\
\hline $\mathrm{Cl}$ & -0.094 & 0.169 & -0.534 & 0.269 & 0.552 & -0.325 \\
\hline $\mathrm{Na}$ & 0.292 & 0.310 & -0.205 & -0.153 & 0.213 & 0.826 \\
\hline K & 0.201 & 0.116 & -0.155 & 0.826 & -0.052 & 0.391 \\
\hline $\mathrm{BOD}_{5}$ & -0.420 & 0.066 & 0.679 & -0.385 & 0.218 & -0.12 \\
\hline COD & -0.668 & -0.441 & 0.223 & -0.045 & -0.440 & 0.131 \\
\hline $\mathrm{PO}_{4}-\mathrm{P}$ & 0.860 & 0.280 & 0.211 & 0.137 & -0.160 & 0.037 \\
\hline $\mathrm{TP}$ & -0.087 & 0.094 & 0.001 & -0.033 & 0.936 & 0.113 \\
\hline $\mathrm{NO}_{3}-\mathrm{N}$ & -0.221 & 0.602 & -0.404 & -0.448 & -0.230 & 0.163 \\
\hline Eigenvalues & 2.724 & 2.429 & 2.126 & 1.971 & 1.721 & 1.672 \\
\hline Total variance (\%) & 19.457 & 17.348 & 15.185 & 14.081 & 12.29 & 11.946 \\
\hline Cumulative variance (\%) & 19.457 & 36.805 & 51.99 & 66.071 & 78.361 & 90.307 \\
\hline
\end{tabular}

\section{Principal component analysis}

Principal component analysis was carried out on the data set of fourteen variables to identify the various parameters and their association. Six principal components (PCs) have been identified by factor analysis which explained $90.30 \%$ of total variance. PC1 explained $19.45 \%$, PC2 $17.34 \%$, PC3 $15.18 \%$, PC4 $14.08 \%$, PC5 $12.29 \%$ and PC6 $11.94 \%$ of the total variance. The eigenvalues, variance, cumulative variance and component loadings are given in Table 2, and the biplot which is the graphical representation of factor loadings in different components is given in Fig. 2.

PC1 explaining $19.45 \%$ of total variance has strong loading on $\mathrm{pH}$ and $\mathrm{PO}_{4}-\mathrm{P}$ and moderate negative loading of COD. The positive loading of $\mathrm{pH}$ is associated with alkaline nature of wastewater, with elevated levels of phosphates mainly from phosphate-based detergents and soaps; thus, PC1 represents alkaline factor. PC2 explaining $17.34 \%$ of variance has strong positive loading of EC, moderate positive loading of $\mathrm{NO}_{3}-\mathrm{N}$ and strong negative loading of TSS; thus, $\mathrm{PC} 2$ represents salts/ions factor. PC3 explaining a variance of $15.18 \%$ has strong positive loading of $\mathrm{Ca}$ and moderate negative loading of $\mathrm{Cl}$, whereas moderate positive loading of $\mathrm{BOD}_{5}$. The negative loading of $\mathrm{Cl}$ indicates the source of $\mathrm{Ca}$ is other than catchment as $\mathrm{Ca}$ is mainly contributed by catchment geology, but its positive association with $\mathrm{BOD}_{5}$ indicated it is added during the usage of water due the addition of organic matter; thus, PC3 represents household/water usage factor. PC4 with a total variance of $14.08 \%$ has strong positive loading of TDS and $\mathrm{K}$ as both of them are in dissolved state; thus, PC4 represents dissolved salts factor. PC5 explaining $12.29 \%$ of total variance has strong positive loading of TP and moderate positive loading of $\mathrm{Cl}$. Phosphates and chlorides are mainly contributed by soaps and detergents, in addition to catchment, thus PC5 represents soap/detergent factor. PC6 with a total variance of $11.94 \%$ has strong positive loading of $\mathrm{Na}$ and moderate positive loading of $\mathrm{Mg}$. $\mathrm{Na}$ is contributed by both catchment and household usage of water, but its association with $\mathrm{Mg}$ indicates its source as catchment since the $\mathrm{Mg}$ is mainly contributed by catchment; thus, PC6 also represents catchment factor. Thus, overall characteristics of the wastewater are attributed by the household usage along with catchment geology.

\section{Conclusion}

The study revealed that SBR-based treatment plant significantly removed the objectionable physiochemical properties of wastewater prior to its discharge into water body, but least reduction in ortho-phosphate, total suspended solids 
Fig. 2 Biplots for principal component analysis $1+2$, $1+3$ and $2+3$ component of wastewater
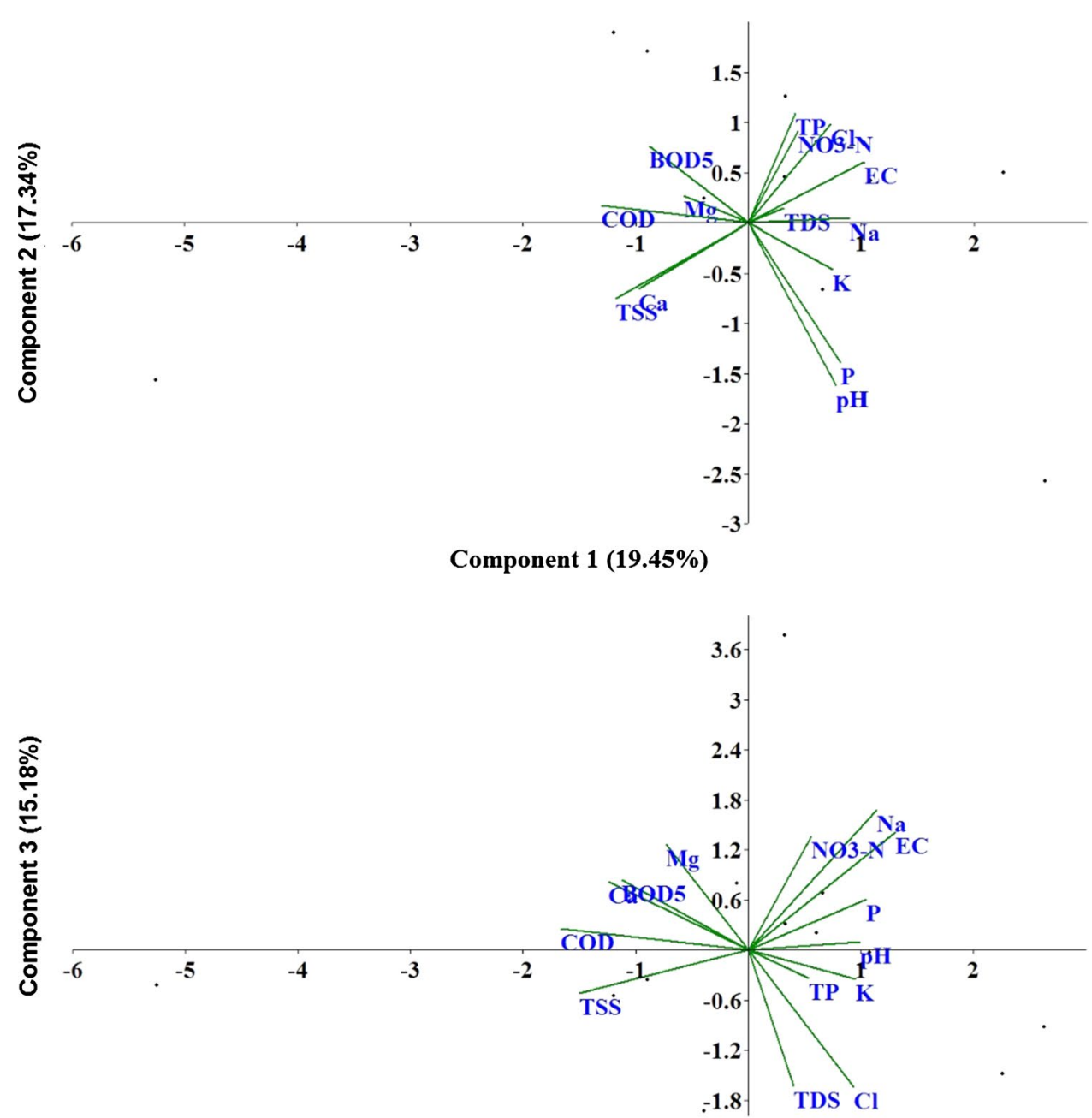

Component 1 (19.45\%)

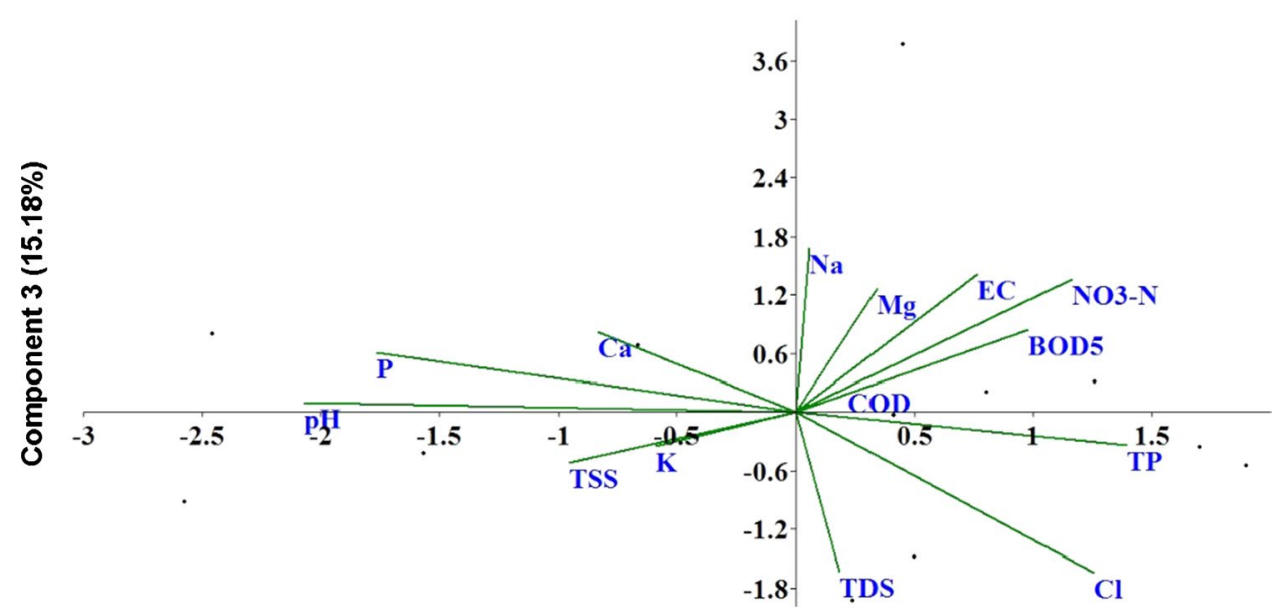

Component 2 (17.34\%) and total dissolved solids is issue of concerns. There is possibility of adverse effects of effluent discharge on receiving water body as it is already under the stress of pollution load, and thus, there should be a continuous monitoring program by the concerned authorities to ensure the best practices/ measures with regard to treatment and discharge of wastewater into the receiving lake system. 
Open Access This article is distributed under the terms of the Creative Commons Attribution 4.0 International License (http://creativeco mmons.org/licenses/by/4.0/), which permits unrestricted use, distribution, and reproduction in any medium, provided you give appropriate credit to the original author(s) and the source, provide a link to the Creative Commons license, and indicate if changes were made.

\section{References}

Aguado D, Montoya T, Ferrer J, Seco A (2006) Relating ions concentration variations to conductivity variations in a sequencing batch reactor operated for enhanced biological phosphorus removal. Environ Model Softw 21(6):845-851

Ajala OJ, Nwosu FO, Ahmedn RK (2018) Adsorption of atrazine from aqueous solution using unmodified and modified bentonite clays. Appl Water Sci 8:214. https://doi.org/10.1007/s13201-018-0855-y

Akan JC, Abdulrahman FI, Dimari GA, Ogugbuaja VO (2008) Physicochemical determination of pollutants in wastewater and vegetable samples along the Jakara wastewater channel in Kano Metropolis, Kano State, Nigeria. Eur J Sci Res 23(1):122-133

APHA (2005) Standard methods for the examination of water and wastewater, 21st edn. American Public Health Association, Washington, DC

Bates RG (1978) Concept and determination of pH. In: Kolthoff IM, Elving PJ (eds) Treatise on analytical chemistry. Part 1, vol 1. Wiley-Interscience, New York, p 821

Bhandari NS, Nayal K (2008) Correlation study on physico-chemical parameters and quality assessment of Kosi River Water, Uttarakhand. E-J Chem 5(2):342-346

Brown L, Bellinger EG (1978) Nitrate determination in fresh and some estuarine waters by ultraviolet light absorption: a new proposed method. Water Res 12(4):223-229

Chen T, Zhang H, Sun C, Li H, Gao Y (2018) Multivariate statistical approaches to identify the major factors governing groundwater quality. Appl Water Sci 8:215. https://doi.org/10.1007/s1320 1-018-0837-0

Claesson S, Steineck S (1996) Plant nutrient management and the environment. Special reports 41. Swedish University of Agricultural and Science, SLU, Uppsala

Ding D, Feng C, Jin Y, Hao C, Zhao Y, Suemura T (2011) Domestic sewage treatment in a sequencing batch biofilm reactor (SBBR) with an intelligent controlling system. Desalination 276:260-265

Dohare D, Kawale M (2014) Biological treatment of wastewater using activated sludge process and sequential batch reactor process-a review. Int J Eng Sci Res Technol 3(11):728-736

Dutta A, Sarkar S (2015) Sequencing batch reactor for wastewater treatment: recent advances. Curr Pollut Rep 1:177-190

Edwards GP, Molof AH, Schneeman RW (1965) Determination of orthophosphate in fresh and saline waters. J Am Water Works Assoc 57:917

Edwin GA, Gopalsamy P, Muthu N (2014) characterization of domestic grey water from point source to determine the potential for urban residential reuse: a short review. Appl Water Sci 4:39-49

Ekama GA, Marais GVR (1984) Nature of municipal wastewaters. Theory, design, and operation of nutrient removal activated sludge processes. Water Research Commission, Pretoria

Emmanuel E, Odjadjare O, Okoh Anthony I (2010) Physicochemical quality of an urban municipal wastewater effluent and its impact on the receiving environment. Environ Monit Assess 170:383-394

Fernandes H, Jungles MK, Hoffmann H, Antonio RV, Costa RHR (2013) Full-scale sequencing batch reactor (SBR) for domestic wastewater: performance and diversity of microbial communities. Bioresour Technol 132:262-268
Gautam SK, Sharma D, Tripathi JK, Ahirwar S, Singh SK (2013) A study of the effectiveness of sewage treatment plants in Delhi Region. Appl Water Sci 3:57-65

Ghehi TJ, Mortezaeifar S, Gholami M, Kalantary RR, Mahvi AH (2014) Performance evaluation of enhanced SBR in simultaneous removal of nitrogen and phosphorous. J Environ Health Sci Eng 12:134. https://doi.org/10.1186/s40201-014-0134-2

Gray NF (1989) Biology of wastewater treatment. Oxford University Press, Oxford

Horan NJ (1990) Biological wastewater treatment systems, theory and operation. Wiley, Chickester

Jafarinejad S (2017) Recent development in the application of sequencing batch reactor (SRB) technology for the petroleum industry wastewater treatment. Chem Int 3(3):241-250

Jan U, Rafiq SK (2012) Efficiency of STP, Hazratbal, J and K, India. Nat Sci 10(11):195-198

Jasper WS (1988) Secondary standard potassium chloride conductivity solutions at $25^{\circ} \mathrm{C}$. Corporate Metrology Laboratory, YSI Inc, Yellow Springs

Johal E, Walia BS, Saini MS, Jha MK (2014) Efficiency assessment and mathematical correlation development between BOD5 and other parameters in Jalandhar Sewage Treatment. Int J Innov Res Sci Eng Technol 3(6):13088-13096

Kat H, Navone R (1964) Methods for simultaneous determination of calcium and magnesium. J Am Water Works Assoc 5:121

Khan AA, Gaur RZ, Mehrotra I, Diamantis V, Lew B, Kazmi AA (2014) Performance assessment of different STPs based on UASB followed by aerobic post treatment systems. J Environ Health Sci Eng. https://doi.org/10.1186/2052-336x-12-43

Khan NA, Hussain A, Changani F, Hussain K (2017) Review on SBR (sequencing batch reactor) treatments technology of industrial wastewater. REST J Emerg Trends Model Manuf 3(4):87-91

Khudair BH, Jasim SA (2017) Performance evaluation of sequencing batch reactor and conventional wastewater treatment plant based on reliability assessment. J Eng 23(11):105-120

Kokkinos P, Mandilara G, Nikolaidou A, Velegraki A, Theodoratos P, Kampa D, Blougoura A, Christopoulou A, Smeti E, Kamizoulis G, Vantarakis A, Mavridou A (2015) Performance of three small-scale wastewater treatment plants. A challenge for possible re use. Environ Sci Pollut Res 22(22):17744-17752. https://doi.org/10.1007/s11356-015-4988-3

Kominko H, Gorazda K, Wzorek Z, Wojtas K (2018) Sustainable management of sewage sludge for the production of organomineral fertilizers. Waste Biomass Valor 9:1817-1826

Kulkarni P (2013) Nitrophenol removal by simultaneous nitrification denitrification (SND) using T. pantotropha in sequencing batch reactors (SBR). Bioresour Technol 128:273-280

Kushwah RK, Bajpai A, Malik S (2011) Characteristics of waste water in STP of Bhopal (India). J Chem Pharm Res 3(6):766-771

Lamichhane J, Upadhyaya BB, Chalise N, Makaju S (2011) Evaluation of waste water treatment units located at different parts of Nepal. Nepal J Sci Technol 12:201-210

Lim J-W, Seng C-E, Lim PE, Ng S-L, Ahmad Sujari A-N (2011) Nitrogen removal in moving bed sequencing batch reactor using polyurethane foam cubes of various sizes as carrier materials. Bioresour Technol 102(21):9876-9883

Mahvi AH, Mesdaghinia AR, Karakani F (2004) Feasibility of continuous flow sequencing batch reactor in domestic wastewater treatment. Am J Appl Sci 1(4):348-353

Mahvi AH et al (2008) Sequencing batch reactor: a promising technology in wastewater treatment. Iran J Environ Health Sci Eng 5(2):9-90

Mancy KH, Jaffe T (1966) Analysis of dissolved oxygen in natural and waste waters. Publ. No. 99-WP-37. U.S. Public Health Service, Washington, DC

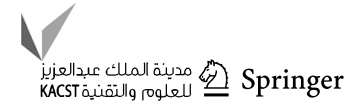


Mehdi M, Rafiq SH (2013) Efficiency of STP, Laam, Nishat, Srinagar, Jammu and Kashmir, India. Nat Sci 11(4):24-29

Metcalf and Eddy (2003) Waste water engineering treatment and reuse, 4th edn. Tata McGraw Hill, New York

Morrison G, Fatoki OS, Persson L, Ekberg A (2001) Assessment of the impact of point source pollution from the Keiskammahoek sewage treatment plant on the Keiskamma River-pH, electrical conductivity, oxygen demanding substance (COD) and nutrients. Water S Afr 27(4):475-480

Najar IA (2017) Vermicomposting of aquatic weeds: a quick review. Plant Sci Today 4(3):133-136. https://doi.org/10.14719/ pst.2017.4.3.311

Najar IA, Khan AB (2011) Assessment of pollution status of Khushalsar Lake, Kashmir, India using multivariate statistical techniques. Pollut Res 30(2):131-136

Najar IA, Khan AB (2012) Assessment of water quality and identification of pollution sources of three lakes in Kashmir, India, using multivariate analysis. Environ Earth Sci 66(8):2367-2378. https://doi.org/10.1007/s12665-011-1458-1

Najar IA, Khan AB (2013) Management of fresh water weeds (macrophytes) by vermicomposting using Eisenia fetida. Environ Sci Pollut Res 20:6406-6417. https://doi.org/10.1007/s1135 6-013-1687-9

Nathanson JA (2003) Basic environmental technology-water supply, waste management and pollution control, 4th edn. PrenticeHall, New Jersey. ISBN 81-203-2228-2

Obaja D, Mace S, Mata-Alvarez J (2005) Biological nutrient removal by a sequencing batch reactor (SBR) using an internal organic carbon source in digested piggery wastewater. Bioresour Technol 96:7-14

Ogunfowokan AO, Okoh EK, Adenuga AA, Asubiojo OI (2005) Assessment of the impact of point source pollution from a university sewage treatment oxidation pond on the receiving stream-a preliminary study. J Appl Sci 6(1):36-43

Patel ZJ, Nakhla G (2006) Simultaneous carbon, nitrogen and phosphorus removal from municipal wastewater in a Circulating Fluidized Bed Bioreactor. Chemosphere 5(7):1103-1112

Patel S, Rajor A, Jain BP, Patel P (2013) Performance evaluation of effluent treatment plant of textile wet processing industry: a case study of narol textile cluster, Ahmedabad, Gujarat. Int J Eng Sci Innov Technol 2(4):290-296

Pitwell LR (1983) Standard COD. Chem Brit 19:907

Popple T, Williams JB, May E, Mills GA, Oliver R (2016) Evaluation of a sequencing batch reactor sewage treatment rig for investigating the fate of radioactively labelled pharmaceuticals: case study of propranolol. Water Res 88:83-92
Rajeb AB, Kallali H, Saidi N, Abidi S, Jedidi N, Hassen A (2011) Physicochemical and microbial characteristics performance in wastewater treated under aerobic reactor. Am J Environ Sci 7:254-262

Rizvi H, Ahmad N, Abbas F, Bukhari IH, Yasar A, Ali S, Yasmeen T, Riaz M (2015) Start-up of UASB reactors treating municipal wastewater and effect of temperature/sludge age and hydraulic retention time (HRT) on its performance. Arab J Chem 8:780-786

Salunke KA, Bhave PP, Mata MM (2014) Performance status of common effluent treatment plant at Dombivati CETP. Int J Res Eng Technol 3(9):48-52

Sekhar PR, Sruthi PL, Kumar KS (2014) Performance evaluation of sewage treatment plant at a point source of hussain sagar lake watershed. Int J Eng Trends Eng Dev 2(4):2249-6149

Sharma P, Khitoliya RK, Kumar S (2013) A comparative study of sewerage treatment plants with different technologies in the vicinity of Chandigarh city. J Environ Sci Toxicol Food Technol 4(5):113-121

Singh S, Varshney M (2013) Evaluation of functioning of waste water treatment plant at Chandramati Education Society, Jaipur: a case study. Asian J Nat Appl Sci 2(2):127-139

Singh A, Kazmi A, Starkl M, Bawa I, Khale P, Patil P, Nimkar I, Naik M (2015) Sewage treatment and management in Goa. A case study. Expo Health, India. https://doi.org/10.1007/s1240 3-015-0183-5

Thompson KC, Reynolds RJ (1978) Atomic absorption, fluorescence, and flame spectroscopy - a practical approach, 2nd edn. Wiley, New York

Tian WD, Li WG, Zhang H, Kang X-R, van Loosdrecht M (2011) Limited filamentous bulking in order to enhance integrated nutrient removal and effluent quality. Water Res 45:4877-4884

Ukpong EC (2013) Performance evaluation of Activated Sludge waste water treatment plant (ASWTP) at QIT, Ibeno local government area of Akwa Ibom state, Nigeria. Int J Eng Sci 2(7):1-13

Von Sperling M (1996) Design of facultative pond based on uncertainty analysis. Water Sci Technol 33(7):41-47

Wakode PN, Sayyad SU (2016) Performance evaluation of 25MLD sewage treatment plant (STP) at Kalyan. Am J Eng Res 3(3):310-316

Wenzel MC, Ekama GA (1997) Principles in the design of single sludge activated sludge systems for biological removal of carbon, nitrogen and phosphorus. In: CEBEDOC (ed) La dephosphataion des eaux use, Belgium vol 8(4), pp 13-26

Publisher's Note Springer Nature remains neutral with regard to jurisdictional claims in published maps and institutional affiliations. 